\title{
SEDIMENTOLOGY AND PALEOECOLOGY OF A DIVERSE EARLY JURASSIC TETRAPOD TRACKSITE IN LESOTHO, SOUTHERN AFRICA
}

\author{
ROGER M. H. SMITH, ${ }^{*}$ CLAUDIA A. MARSICANO, ${ }^{2}$ and JEFFREY A. WILSON ${ }^{3}$ \\ ${ }^{1}$ Department of Karoo Palaeontology, Iziko South African Museum, Cape Town, 8000, South Africa; ${ }^{2}$ Departamento de Ciencias Geológicas, Universidad de Buenos \\ Aires, C1428 EHA, Buenos Aires, Argentina; ${ }^{3}$ Museum of Paleontology \& Department of Geological Sciences, University of Michigan, 1109 Geddes Road, Ann Arbor, \\ Michigan 48109-1079, USA \\ e-mail: rsmith@iziko.org.za
}

\begin{abstract}
An Early Jurassic tetrapod tracksite in the upper Elliot Formation at Moyeni, southern Lesotho, displays a variety of trackways attributed to large- and medium-sized theropod (Neotrisauropus-type) and ornithischian (Moyenisauropus-type) dinosaurs, basal crurotarsal archosaurs (chirotheroid-type), and a short-legged basal tetrapod (Episcopopustype). The tracks are on a low-angle pointbar and are buried with loessic floodplain fine-grained sediment. Calcic paleosols indicate a warm semiarid climate. Many of the footprints were imprinted through an algal mat in a water-margin setting. Convergence of several trackways toward a single point suggests repeated visits to drink or cross the river. One of the two large Moyenisauropus-type trackways has a narrow gauge that suggests an upright, parasagittal gait, whereas the other shows changes in gauge width, stance, and posture as it proceeded up the pointbar slope. At least three resting traces with manus, metatarsal, and tail impressions attributable to the Moyenisauropus-type ornithischian are also preserved. Discovery of two manus-pes pairs of chirotheroid-type footprints in the Moyeni section highlights a mismatch between the bodyfossil and trace-fossil records. Chirotheroid tracks are generally thought to be restricted to the Triassic, and their discovery at the Moyeni tracksite compounds the problem of where to place the Triassic-Jurassic boundary in this succession. Three possible scenarios could explain the occurrence of chirotheroid-type tracks at Moyeni: (1) the tracksite is Late Triassic in age; (2) the chirotheroid tracks were made by archosaurs other than basal crurotarsans; (3) the tracks are correctly identified and the age of the Moyeni section is correctly assigned, but the inferred range of chirotheroid-type tracks is incorrect. We suggest that the latter two are the most likely explanations.
\end{abstract}

\section{INTRODUCTION}

Vertebrate fossils are relatively common in the Lower Jurassic upper Stormberg Group of Karoo-aged basins of southern Africa, but they are of relatively low diversity and are dominated by the prosauropod dinosaur Massospondylus (Kitching and Raath, 1984). In contrast, contemporaneous floodplain paleosurfaces, especially in the upper Elliot Formation, preserve diverse assemblages of tetrapod footprints that were, in their original description, ascribed to more than 56 ichnospecies (Ellenberger, 1970, 1974). These were later reduced by synonymy to 5 ichnogenera (Olsen and Galton, 1984). If it is accepted that all these tracktypes were made by different trackmakers, then they represent a much greater diversity of tetrapod taxa than is indicated by the body fossils and, thus, would be a useful source of additional information about the faunal communities at the time.

In this study, we combine sedimentological and ichnological analyses of one of these trackway sites, Moyeni (Quthing) in southern Lesotho, to test the validity of the numerous ichnospecies and learn more about

* Corresponding author.

Copyright $\odot$ 2009, SEPM (Society for Sedimentary Geology) the composition of Early Jurassic tetrapod faunas in southern Gondwana (Fig. 1). We demonstrate that the apparent diversity in tracktypes can be attributed to several causes other than biological diversity. Along some trackways, the footprint morphology changes with variations in media consistency and slope as well as adjustments in the locomotion of the animal.

Fossil footprints were first discovered in Lesotho in mid-1881 by French missionaries, Dr. Eugene Casalis and Rev. Robert Henry Dyke, while picnicking behind the Morija mission station (Ambrose, 2007). They found a set of large tridactyl prints preserved in epirelief on the base of a fallen block of Clarens sandstone. A few years later Frédéric Christol (1897, p. 298) described a sketch of these tracks with "petrified footprints of birds or of lizards." Recently Ellenberger et al. (2006) reported on Bushman paintings dated between 1810 and 1820 in Lesotho that depict a three-toed footprint along with painted outlines of a bipedal animal that resembles modern reconstructions of ornithopod dinosaurs. If these paintings are genuine, this would be the earliest report of dinosaur tracks in Africa.

Another French missionary, Dr. Paul Ellenberger, conducted the most extensive and thorough scientific investigation of the Lesotho dinosaur tracksites to date. From 1953 to 1970, he mapped and described 170 ichnospecies of fossil tracks from 58 sites throughout the country, mostly within the Elliot and Clarens formations, but including at least 2 from underlying Burgersdorp strata (Ellenberger, 1972, 1974). He focused on the Moyeni paleosurface in southern Lesotho, which he considered to be the most diverse Late Triassic footprint site with over 47 different track types (Fig. 1). Olsen and Galton (1984) subsequently synonymized all but one of Ellenberger's ichnotaxa with previously described tracks from Lower Jurassic strata of Europe and North America, thus reducing the number of Moyeni tracktypes to four. Following Olsen and Galton's (1984) Early Jurassic date for the Moyeni footprints, the Triassic-Jurassic boundary in the main Karoo Basin was positioned roughly midway through the Elliot Formation at a large spherical nodule horizon marking the last occurrence of such large prosauropods as Euskelosaurus and the first occurrence of the smaller prosauropod Massospondylus (Fig. 2; Kitching and Raath, 1984). In this study, we retain Ellenberger's ichnotaxa to facilitate identification of individual trackways at the Moyeni site and use the suffix -type to recognize that there are ichnotaxonomic issues that need to be clarified but cannot be addressed here.

\section{GEOLOGICAL SETTING}

The Upper Triassic to Lower Jurassic Elliot Formation is a fluvial redbed succession that accumulated in the center of the continental main Karoo Basin of southwestern Gondwana under progressively more arid climatic conditions (Eriksson, 1985). The Elliot Formation, whose provenance is mainly from the Gondwanide orogenic belt to the south, thins northward from a maximum of $480 \mathrm{~m}$ at the study site in southern Lesotho to $<30 \mathrm{~m}$ in the northern Free State of South Africa 


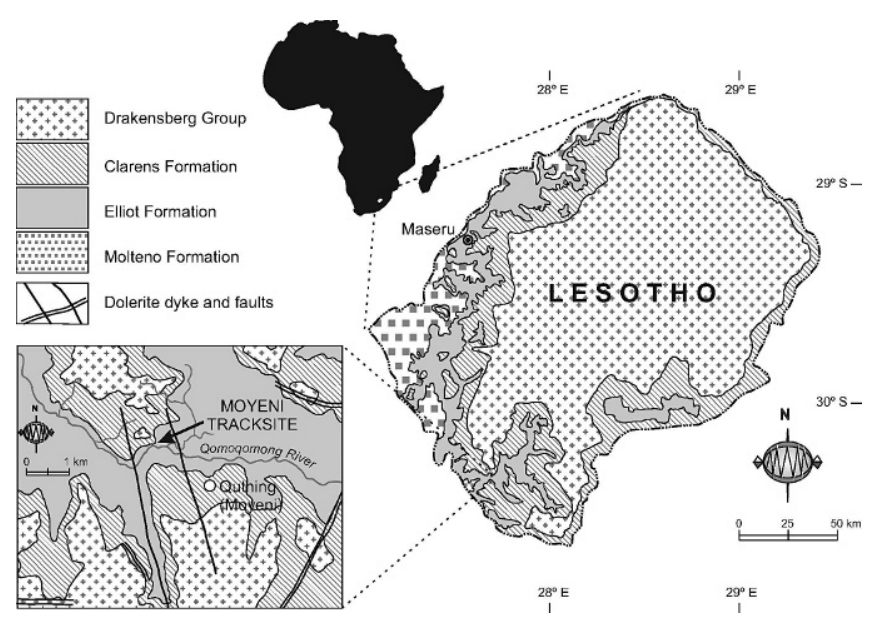

FIGURE 1-Regional geology of the Moyeni dinosaur tracksite in southern Lesotho.

(Fig. 1). Catuneanu et al. (1998) interpreted the tectonic setting of the Elliot basin as a reciprocal foresag crustal flexure landward of the eastwest-trending foredeep in front of the Cape Fold Belt. They cite the rapid northward thinning of the Elliot Formation as it passes over the edge of the stable Kaapvaal Craton as evidence in support of this interpretation.

Paleontological evidence suggests that the age of the Elliot Formation ranges from Upper Triassic (Norian) for the lower Elliot strata to lower Lower Jurassic (Toarcian) for the upper Elliot strata
(Kitching and Raath, 1984). These estimates are in reasonable accordance with a single radiometric date of $183 \mathrm{Ma}$ for lavas interbedded with the top of the overlying Clarens Formation (Fig. 2; Duncan et al., 1997), but the exact positioning of the Triassic-Jurassic boundary is still unresolved.

The diachronous transitional facies relationship of the Elliot Formation with underlying braidplain deposits formed in a humid climate of the Molteno Formation and the overlying ephemeral stream and barchanoid dune deposits of the Clarens Formation is highly suggestive of a continuum of laterally juxtaposed environments with an overriding climatic aridification (Fig. 2; Visser and Botha, 1980; Smith et al., 1993). The paleoenvironment represented by the Elliot Formation is interpreted as a distal arid alluvial plain dominated by rubified floodplain mudrock with thick lenticular medium and highsinuosity channel sandstone bodies in the lower strata and more tabular crevasse-splay and multistory sheet sandstones of a flood fan-dune facies (Visser and Botha, 1980, p. 60) in the upper part. The pinkish red color is primarily due to pedogenic and early diagenetic oxidation of iron derived from ferruginous silicate and clay minerals in the alluvium (Eriksson, 1985). Toward the upper contact with the eolianites of the Clarens Formation through the so-called transition beds (Visser and Botha, 1980), the Elliot Formation is dominated by massively bedded loessic siltstone beds with columnar ped structures, vertically oriented carbonate rhizoliths and calcified fissures (Smith and Kitching, 1997). It is not uncommon to find intervals of dark grey conchostracan-bearing playa mudstones (Kitching and Raath, 1984; Bordy et al., 2004), which indicate the gradual change from the warm temperate to hot, arid conditions in this part of Pangea (Kent and Tauxe, 2005; Rowe et al., 2007).

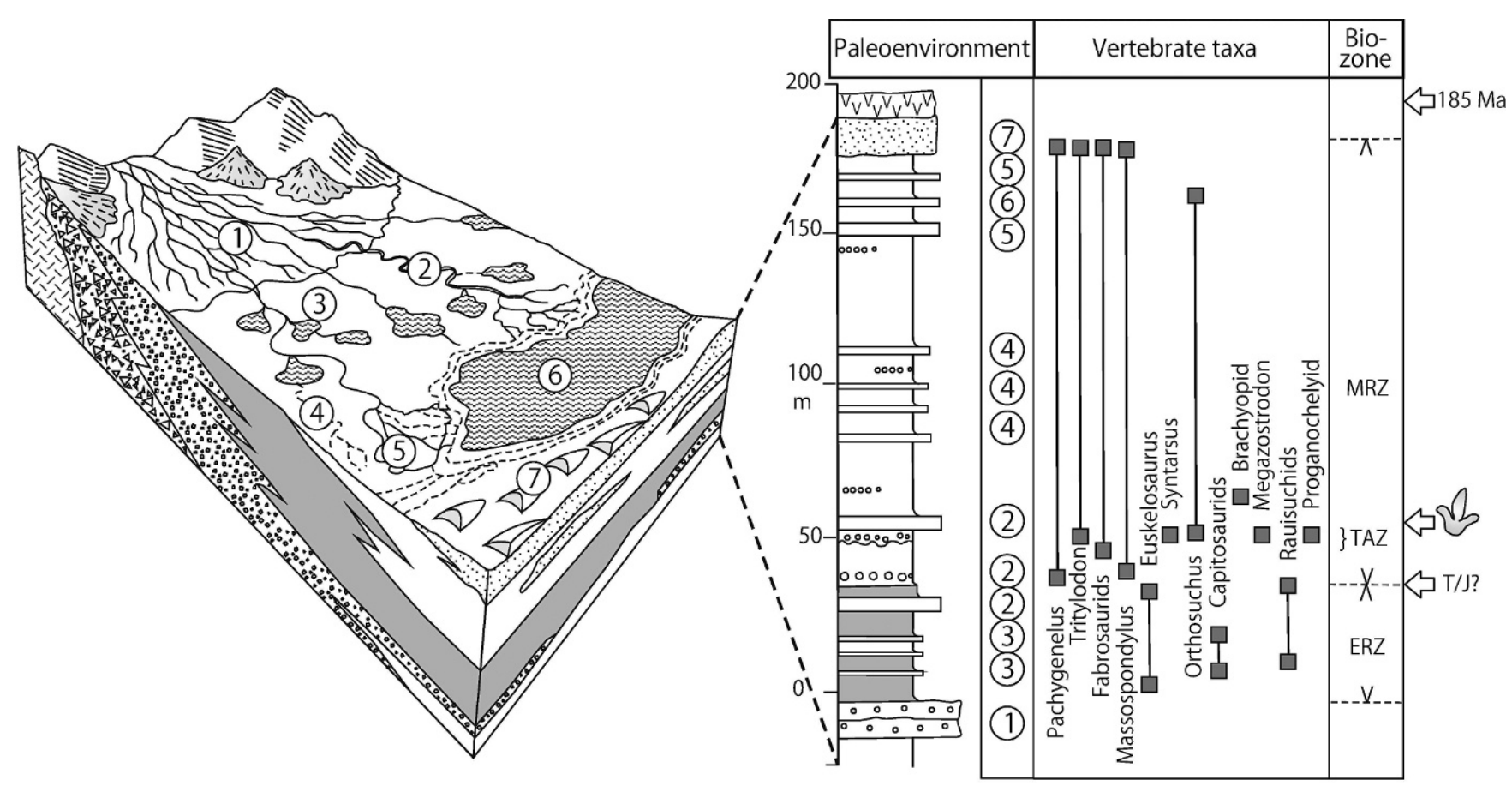

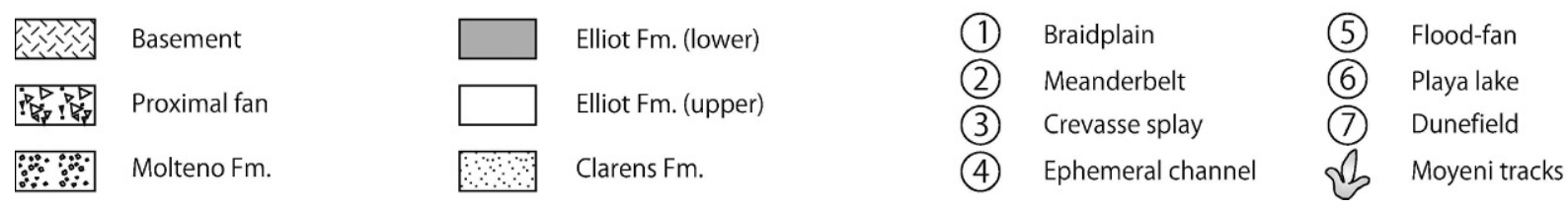

FIGURE 2-Paleogeographic setting, biostratigraphy, and lithostratigraphy of Stormberg Group in Moyeni district of southern Lesotho. Biostratigraphic ranges and zonation from Kitching and Raath (1984). ERZ = Euskelosaurus range zone; TAZ = Tritylodon acme zone; MRZ = Massospondylus range zone. 


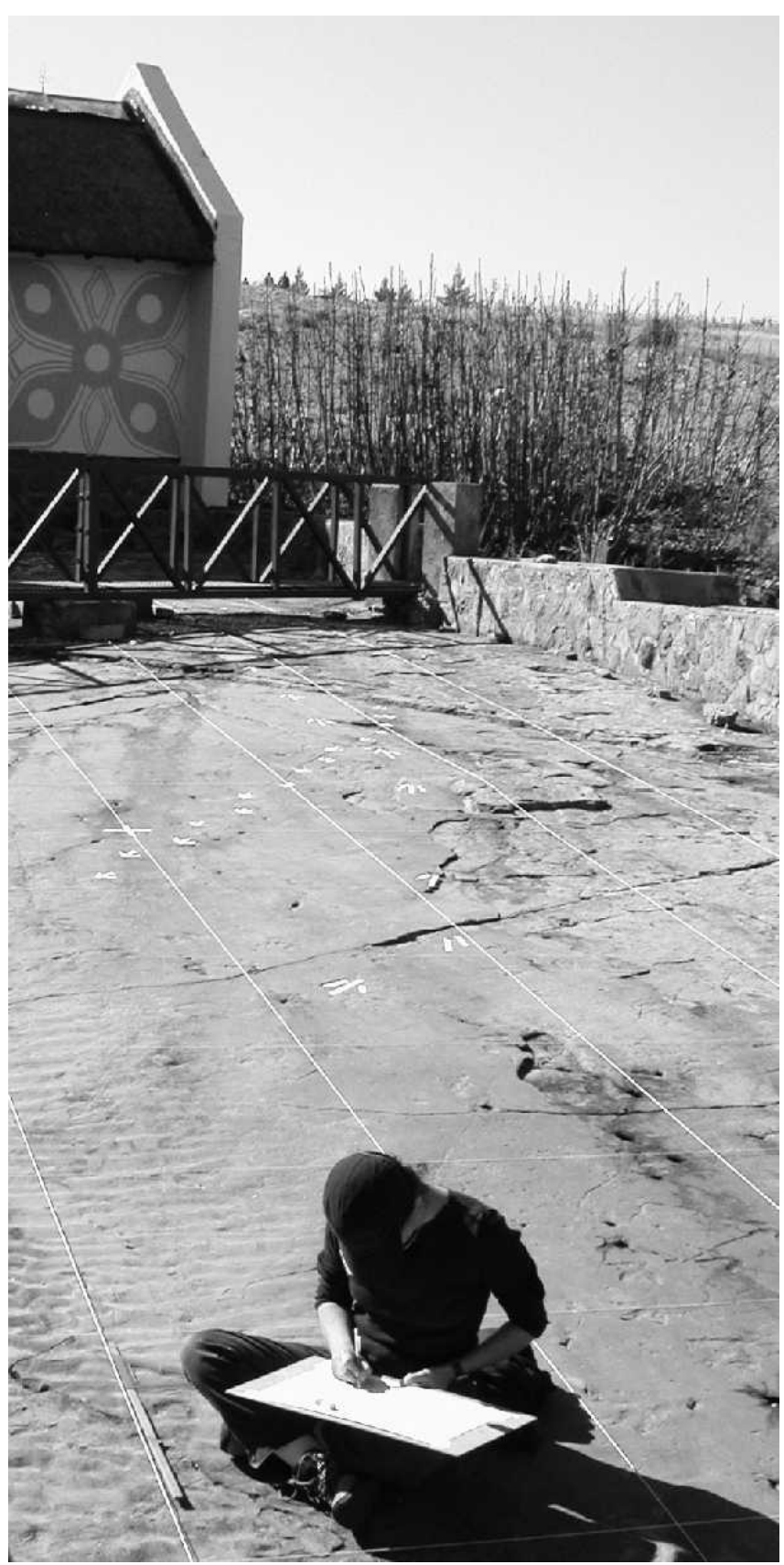

FIGURE 3-General view of part of Moyeni dinosaur tracksite showing ripplemarked flanks and smooth top of an elongate bar.

\section{PALEOENVIRONMENT OF THE MOYENI TRACKSITE}

Ellenberger (1974) interpreted the depositional environment of the Moyeni tracksite as an emergent elongated sandbank formed at the mouth of a river issuing into a large lake. Noting that many of the oscillation ripples were structures caused by wind shear on shallow water, he was convinced that the surface was for the most part an island surrounded by water. He was also aware of some of the overlying mudrocks having loessic characteristics and remarked on fossil desert rose structures in the playa facies. While accepting Ellenbergers's (1974) observations and interpretation as basically sound, here we interpret the sedimentary sequence below and above the paleosurface as having accumulated on the inside bank of a meander loop rather than in a lacustrine setting, with the main trackway surface preserved on one of several scroll bars making up a low-angle point bar.
The main trackway exposure at Moyeni (Fig. 3) is on the upper surface of one of several fine-grained sandstone beds that emanate from the top of a $4 \mathrm{~m}$-thick sandstone body and interfinger with overlying mudrocks (Fig. 4). When followed down into the main sandstone body, the beds thicken to form one of six laterally overlapping accretion units separated by gently dipping scour surfaces. The units are from $0.5 \mathrm{~m}$ at the base of the sandstone to $0.15 \mathrm{~m}$ thick as they protrude from the top. The lower parts of each accretion unit are trough cross-bedded but pass upward into ripple cross-stratification. Where directly overlain by mudrock, the upper surface is commonly covered with small current ripple forms. In cliff-section exposures, the irregular scour surfaces at the base of each accretion unit can be traced laterally for distances of 50-60 m. From close to the base of the sandstone, these units climb upward at an angle of roughly $20^{\circ}$ and terminate at the base of one of the sandstone tongues. These scours are interpreted as hiatal surfaces between lateral accretion events in a river with highly fluctuating flow regime; they represent one of the main indicators of deposition in meandering rather than straight or braided fluvial channels (Allen, 1963; Schumm, 1972; Shepherd, 1987).

Paleocurrent directions recorded mainly from rib and furrow structures on the tracksite surface and surrounding area (within $\sim 150 \mathrm{~m}$ ) show a distinct swing through nearly $160^{\circ}$ from SSW-NE (Fig. 5). The same paleocurrent trend is indicated by the few trough cross-bedded scour fills exposed on this surface (Fig. 6A). Figure 6B shows meter-scale terrace structures on the Moyeni surface that are arcuate in plan view and elongate in the direction of paleoflow. The interference ripple structures covering their convex surface attest to bidirectional shallow water flows similar to those observed on the Usri river point bar in India (Purkait, 1983). Such a pattern of paleocurrent directions on the upper surface of a laterally accreted, fine-grained sandstone body is compelling evidence that the Moyeni tracksite is preserved on the lower slopes of a low-angle point bar, some $150 \mathrm{~m}$ wide, with a dip of $\sim 20^{\circ}$ toward the channel thalweg (Fig. 7).

Mudrocks immediately overlying the track-bearing sandstone are uncharacteristically olive-green rather than the common reddish brown that is considered to be the primary state for upper Elliot Formation mudrocks (Bordy et al., 2004). Here, the color change is almost certainly the result of contact metamorphism from a nearby dolerite sill (see base of section, Fig. 4) and does not have any paleoenvironmental significance. Evidence for semiarid paleosols in this facies includes calcified rectilinear shrinkage fissures, arcuate slickensided claystone-lined skew planes, horizons of oblate calcareous nodules sometimes reworked into shallow depressions (Smith and Kitching, 1997), rough-surfaced horizontal and vertical rhizocretions with distinctive rectilinear bends, and fossil bones commonly coated with, and rarely expanded by, hematite mineralization. This suite of paleopedogenic structures is interpreted as having formed in immature calcic vertisols (Blodgett, 1985; Gustavson, 1991), which suggests relatively fast aggradation rates on warm (mean annual temperatures of $24-27^{\circ} \mathrm{C}$ ), seasonally wet (mean annual rainfall $500-700 \mathrm{~mm}$ ) floodplains.

In the upper Elliot Formation, body fossils are most common in overbank red mudrocks. During this investigation, three semiarticulated Massospondylus skeletons and a scatter of fabrosaurid limb bones, ribs, and vertebrae were found in the Moyeni section (Fig. 4). These specimens, like most of the fossils from the upper Elliot, are preserved in 1-3-m-thick, massive loessic siltstone beds. Although lacking mature caliche horizons, these beds do display horizons of claystone-lined, columnar ped structures indicating immature vertisol development (Smith and Kitching, 1997). The articulated bones are uncrushed, nonweathered, and only lightly encrusted with a dark reddish brown hematite-rich precipitate. This taphonomic style is typical of the Massospondylus range zone (Kitching and Raath, 1984; 


\section{Stratigraphy of Moyeni District}

\begin{tabular}{|c|}
\hline LOWER \\
DRAKENS- \\
BERG \\
GROUP \\
\hline CLARENS \\
FORM- \\
ATION \\
\hline \\
\\
\\
EORIOT \\
ATION \\
UPPR \\
\\
\end{tabular}

Sedimetology of Moyeni tracksite
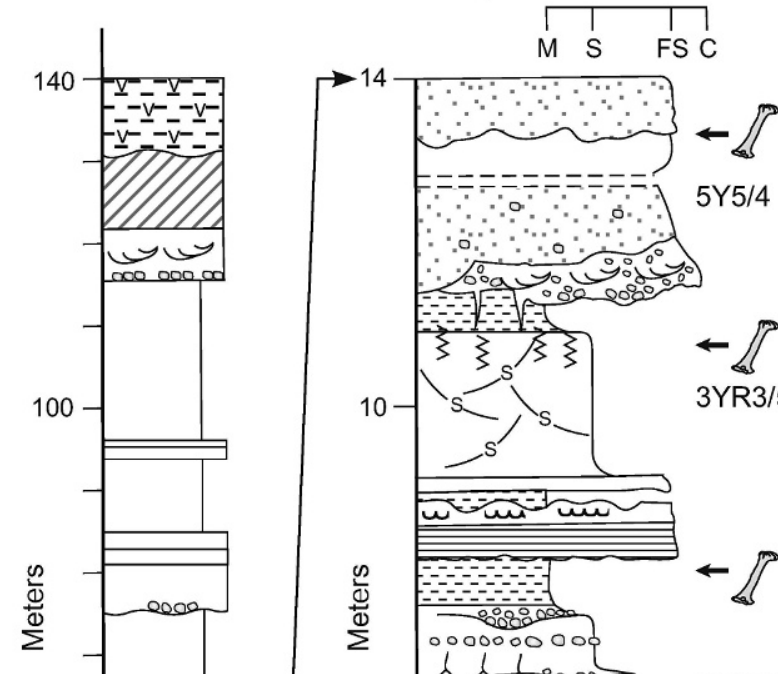

Paleoenvironment

$\stackrel{\Phi}{\Sigma}$
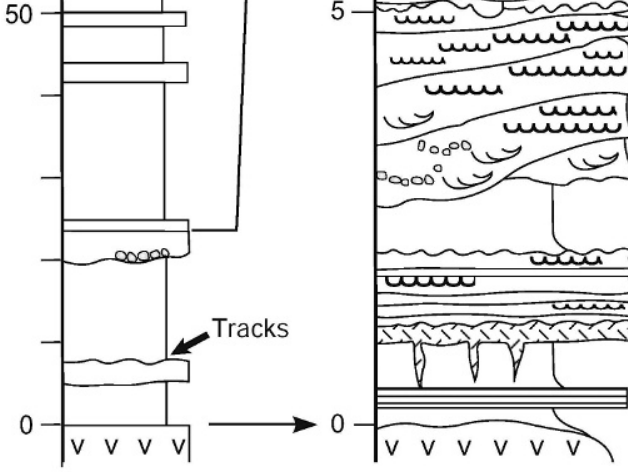

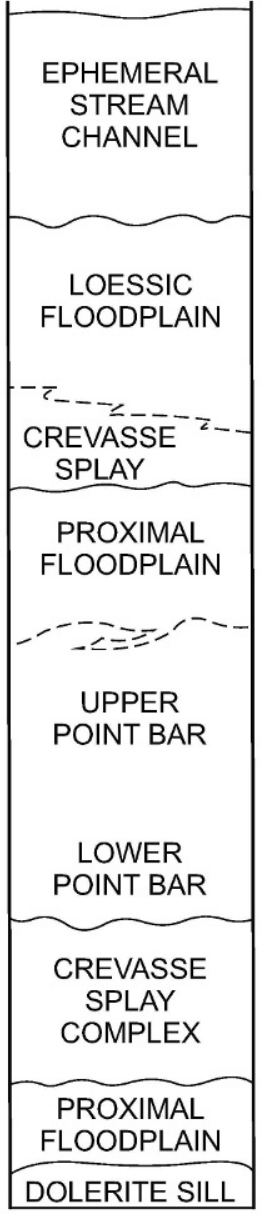

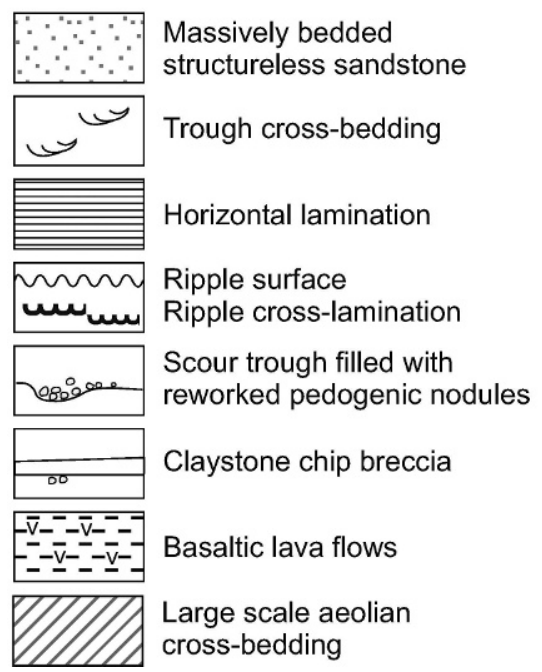

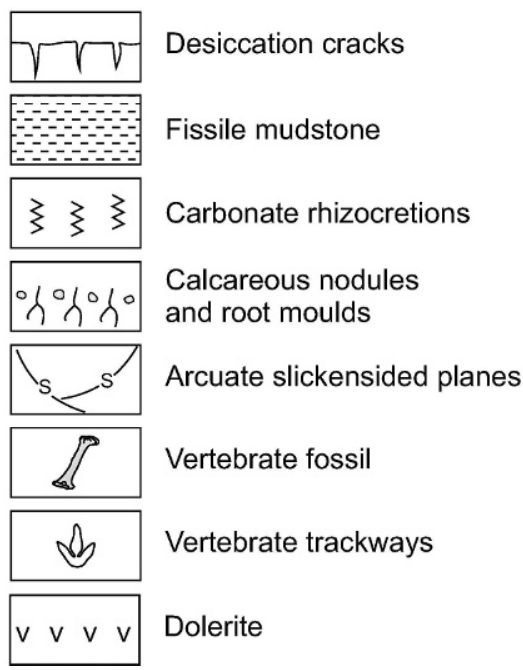

FIGURE 4-Sedimentology and interpreted depositional environment of Moyeni dinosaur tracksite.

Fig. 2) and confirms that the floodplain habitat of these relatively small herbivorous prosauropod and basal ornithischian dinosaurs was periodically covered with a thick layer of windblown dust. These dust storms rapidly buried skeletons exposed on the surface, and by increasing the floodplain accretion rate, they effectively prevented the soil profiles in this facies from reaching maturity.

\section{SEDIMENTOLOGY AND ICHNOLOGY}

The Depositional Event

The Moyeni paleosurface, like many others in the Elliot Formation, was deposited during a single flood event followed by a brief period of 


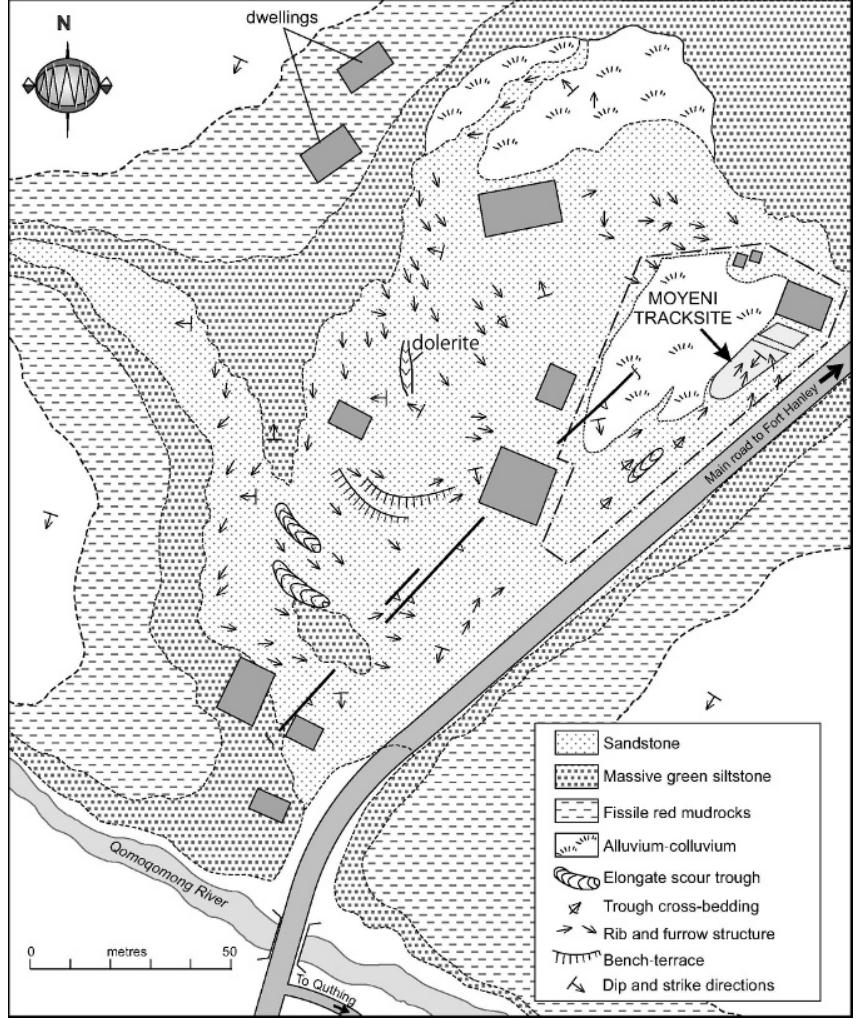

FIGURE 5-Sedimentation of Moyeni tracksite sandstone; paleocurrent directions measured from exposures of track-bearing sandstone surrounding Moyeni tracksite.

emergence when the sedimentary bedforms were overprinted with runoff, falling water level, and desiccation features, as well as a wide range of vertebrate and invertebrate tracks and trails before being buried in a similar flood event. Like a snapshot of the ancient floodplains, they contain valuable information of the fluvial hydrology, sedimentation, local climate, and biological activity.

Figure 8 is a compilation of the sedimentary structures and invertebrate trace fossils visible on the surface of the Moyeni scroll bar. The exposure has an elongate, flat-topped convex bar form with a northeast-southwest trend and sloping surfaces dipping $\sim 25^{\circ}$. Asymmetrical, small current ripples, parting lineation, and small-scale trough cross-bedding (Fig. 8) all indicate a northeasterly unidirectional flow for the main depositional event interpreted as the waning stages of a channel-confined flood surge. Straight to mildly sinuous-crested ripple forms are preserved all along the lower slopes of the bar. Above the rippled zone is a smooth surface where most of the finely imprinted invertebrate traces are visible. Over the flat bar top, the sandstone has a distinctively pustular surface texture (Fig. 8), and it is in this zone that most of the vertebrate footprints are preserved.

It is likely that during peak discharge, as the transverse barform migrated onto the point bar, it was entirely covered with ripples. Only during waning flood did the sand surface become modified into these 3 zones where shoaling caused washout of the bar-top ripples, followed by emergence and runoff. Dendritic rills and semicircular patches of wrinkle marks preserve evidence of the latter (Fig. 9A). It is possible that the dish-shaped wrinkle structures are undertracks but as they are not paired or regularly spaced, this seems unlikely. The absence of desiccation cracks and comparison with similar emergence features in modern arid zone rivers (e.g., Kuiseb River in Namibia, Ward, 1987; Smith, 1993) makes it likely that the Moyeni paleosurface was only exposed for 10 days or so. The pustular surface texture on the bar top is superficially similar to adhesion warts or runzel marks imparted by wind shear on exposed damp sand (Reineck and Singh, 1975). Closer
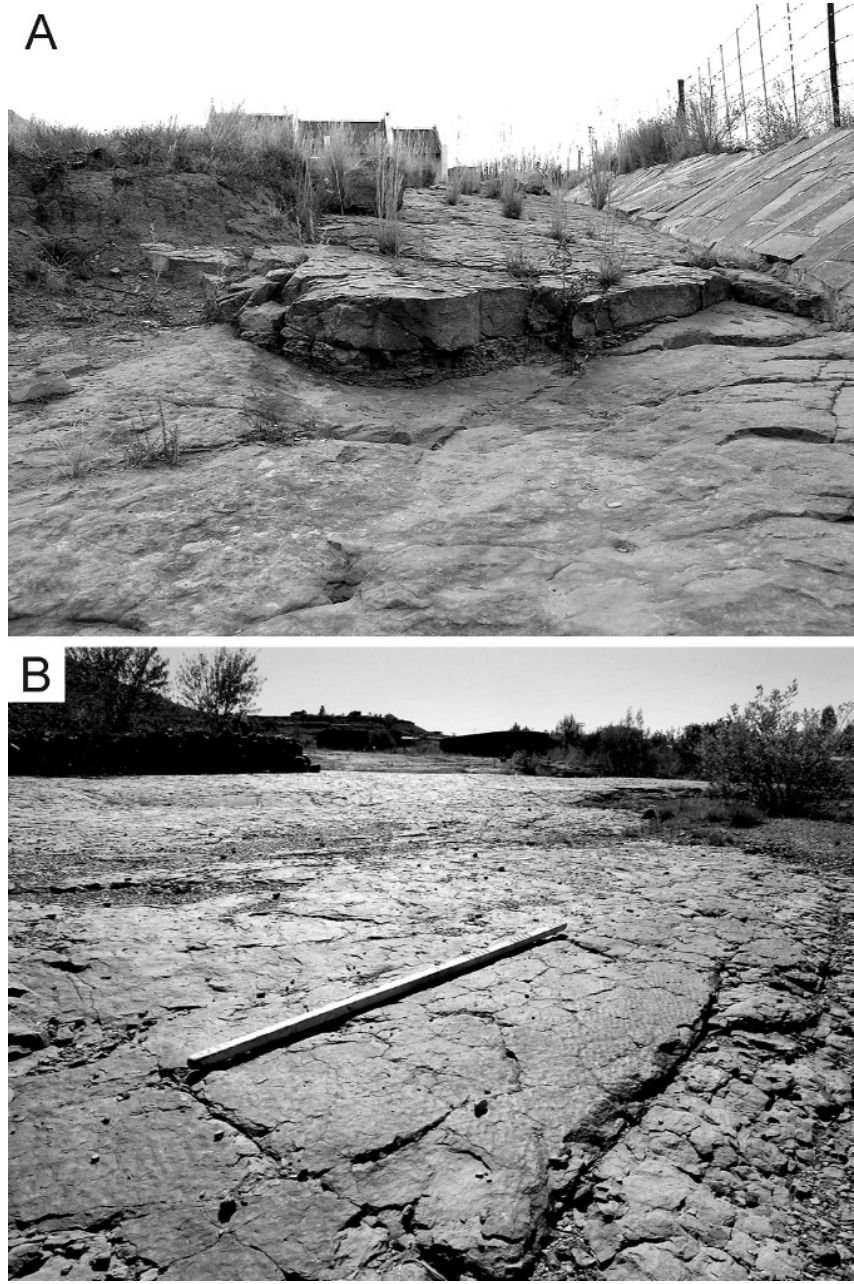

FIGURE 6-Sedimentation of Moyeni tracksite sandstone; A) Trough cross-bedded sandstone filling an elongate scour immediately beneath track-bearing surface $\sim 25 \mathrm{~m}$ southwest of tracksite (see Fig. 5). Scour measures $10.5 \mathrm{~m}$ long by $1.6 \mathrm{~m}$ wide. B) Ripple-marked crescentic bar with falling water-level terraces located on top of same point bar as tracksite. See Figure 5 for exact location. Staff $=1 \mathrm{~m}$ long.

inspection, however, shows the texture to be smoother and more regular than that normally associated with wind action. An alternative explanation is that the surface was sculptured by drying and shrinking of a Spirogyra-like algal mat that was lowered onto bar top as the water level dropped and formed Kinneya-type wrinkle structures (Porada et al., 2008) on the underlying sand surface. The latter interpretation implies one or two periods of restricted flow or ponding of water in a swale setting, allowing time for the algae to propagate. Such slackwater conditions are evidenced by a very fine grained sand veneer that has settled out of suspension onto the bar surface and in which the runoff rills, wrinkle marks, and invertebrate trails were subsequently preserved. Sand volcanoes (Fig. 9B) that erupted on the flanks of the bar at this time were probably caused by methane gas escaping from anaerobic decomposition of buried organic matter.

Invertebrate colonization of the bar began while it was still partially submerged. Sinuous, threadlike grooves on the surface are interpreted as the feeding trails of nematodes and distinctive beaded trails (c.f. Homosiroidea meandrica; Fig. 9D) probably imply the foraging behavior of aquatic isopods (Netto et al., 2009) or possibly insect larvae (Chamberlain, 1975). These are common elements of the subaqueous freshwater Mermia ichnofacies (Buatois and Mángano, 1995); however, these types of traces have been observed in moist terrestrial sediments rather than in ephemeral pools of standing water (Hasiotis, 2008) and suggest terrestrial conditions in ancient deposits 


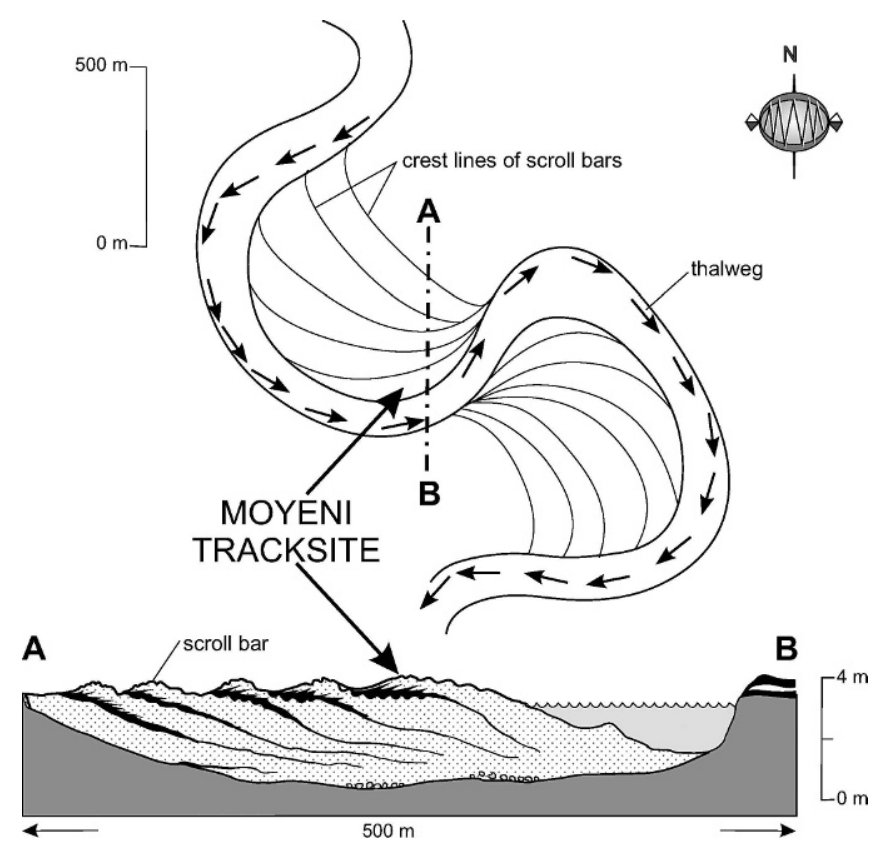

FIGURE 7-Reconstruction of interpreted position of Moyeni tracksite on ancient point bar.

(e.g., Hasiotis, 2004). As interstitial water drained from the exposed bar top, it was colonized by scratch burrowers, probably scarabaeid beetle larvae, that foraged for organic fines in the sediment and left behind numerous unlined, backfilled, meniscate burrows referable to the ichnogenus Naktodemasis (Figs. 8, 9C; Smith et al., 2008; Counts and Hasiotis, 2009).

\section{Tetrapod Activity}

More than 250 tetrapod footprints and trackways are preserved on the Moyeni exposure, all as natural molds, and have no preferred direction of movement. In this study, the entire exposed surface was mapped using a $1 \mathrm{~m}$-square grid, and all preserved footprints were individually drawn to a scale of 1:10 (Fig. 10). Footprints are more abundant and particularly well preserved on the algal-mat-bound surface of the bar top, although several trackways continue downslope into the ripple-marked area of the bar. Many of the tracks are superimposed, indicating the area was visited frequently over a short period of time. Analysis of the alignment of the main trackways indicates three separate points where a number of trackways both converge and radiate, suggesting repeated visits to these particular spots.

Neotrisauropus-Type Footprints.-Numerous large footprints form a single trackway tangential to the length of the scroll bar (Fig. 10). The footprints are tridactyl, elongate, and digit III projects farther anteriorly than digits II and IV (Fig. 11). The well-preserved pads of the digits imply a 3-4-5 phalangeal formula; there are no traces of digit $\mathrm{V}$ or the metatarsus. Impressions of digits II-IV bear distinctively pointed claw marks. The trackway consists of 25 consecutive tridactyl prints with an average pes print length of $28 \mathrm{~cm}$. The long axes of the relatively narrow tracks parallel to the midline and the average divarication angle between digits II and III and III and IV is $25^{\circ}$. Neotrisauropus-type tracks were made by an obligatory-bipedal, functionally tridactyl animal in which the foot impressions almost lie on a straight line. Track dimensions give a calculated hip height of $\sim 1.4 \mathrm{~m}$ (Thulborn, 1989; Henderson, 2003). The parasagittal gait, tridactyl footprints with a distinct divergence between digit IV and digits II and III and pointed claw marks support the hypothesis that the Neotrisauropus-type footprints were made by theropod dinosaurs (J. Wilson, personal communication, 2009).

The ichnotaxon Neotrisauropus was erected by Ellenberger (1970, 1974) to include a series of relatively large tridactyl bipedal footprints from several sites in Lesotho, including the Moyeni site. It was subsequently synonymized with Grallator by Olsen and Galton (1984).

Moyenisauropus-Type Footprints.-The Moyeni assemblage includes at least two long trackways representing facultative bipedal progression (Fig. 12A). These trackways were made by trackmakers similar in size to Neotrisauropus, with an average footprint length of $22 \mathrm{~cm}$. Pes prints are functionally tridactyl, but impressions of digit I and the metatarsus are present in some tracks. The footprints are rotated inward $\left(\sim 20^{\circ}\right)$ with respect to the trackway midline. Internal digits (II, III, IV) of the pes are relatively broad, spread apart, and bear blunt unguals. In contrast with the Neotrisauropus-type footprints, pedal digit II is commonly divergent from digits III to IV. Moyenisauropus manus prints are much smaller than the pes, pentadactyl, rotated outward, and generally imprinted in front of and slightly external to the pes prints
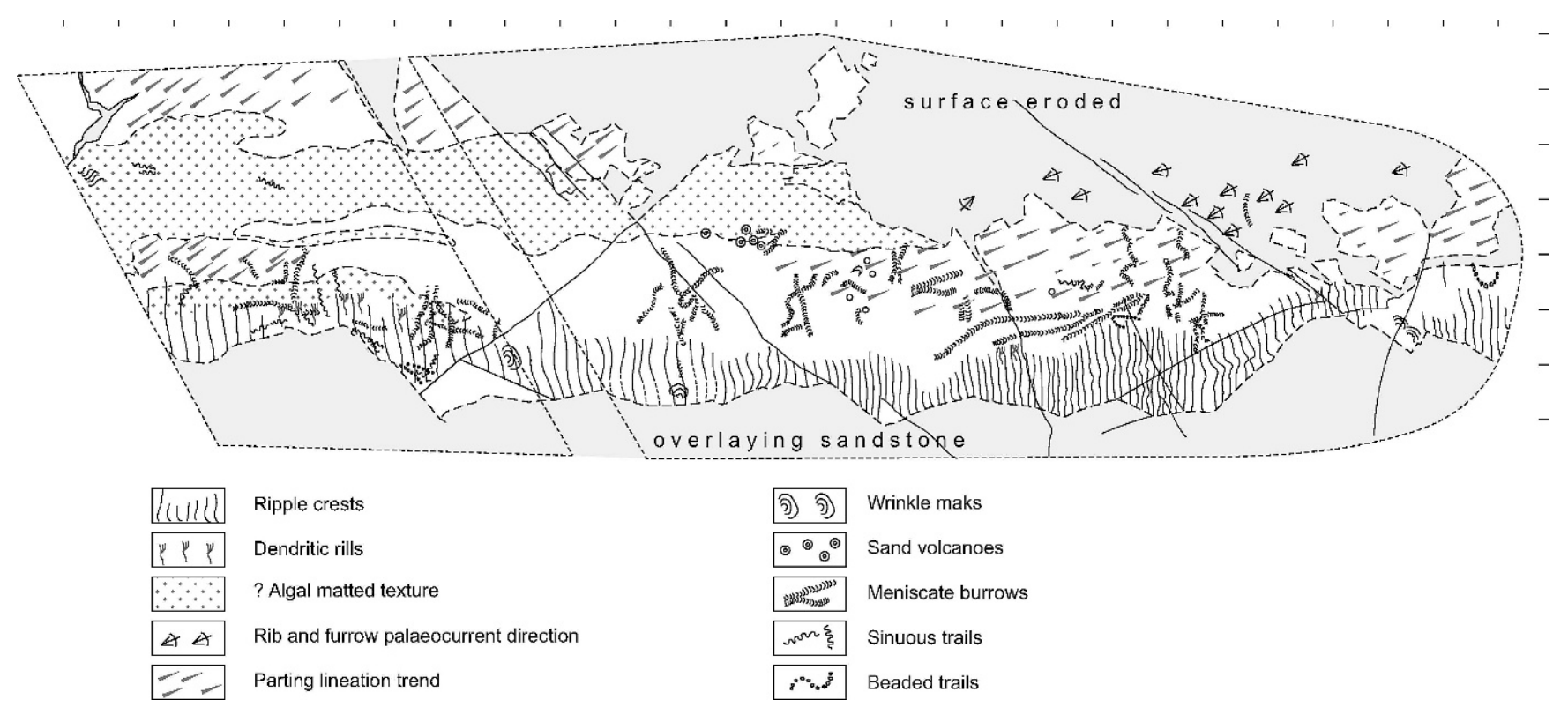

FIGURE 8-Distribution of sedimentary structures, emergence features, and invertebrate trace fossils on Moyeni paleosurface. Tick marks in meters. 

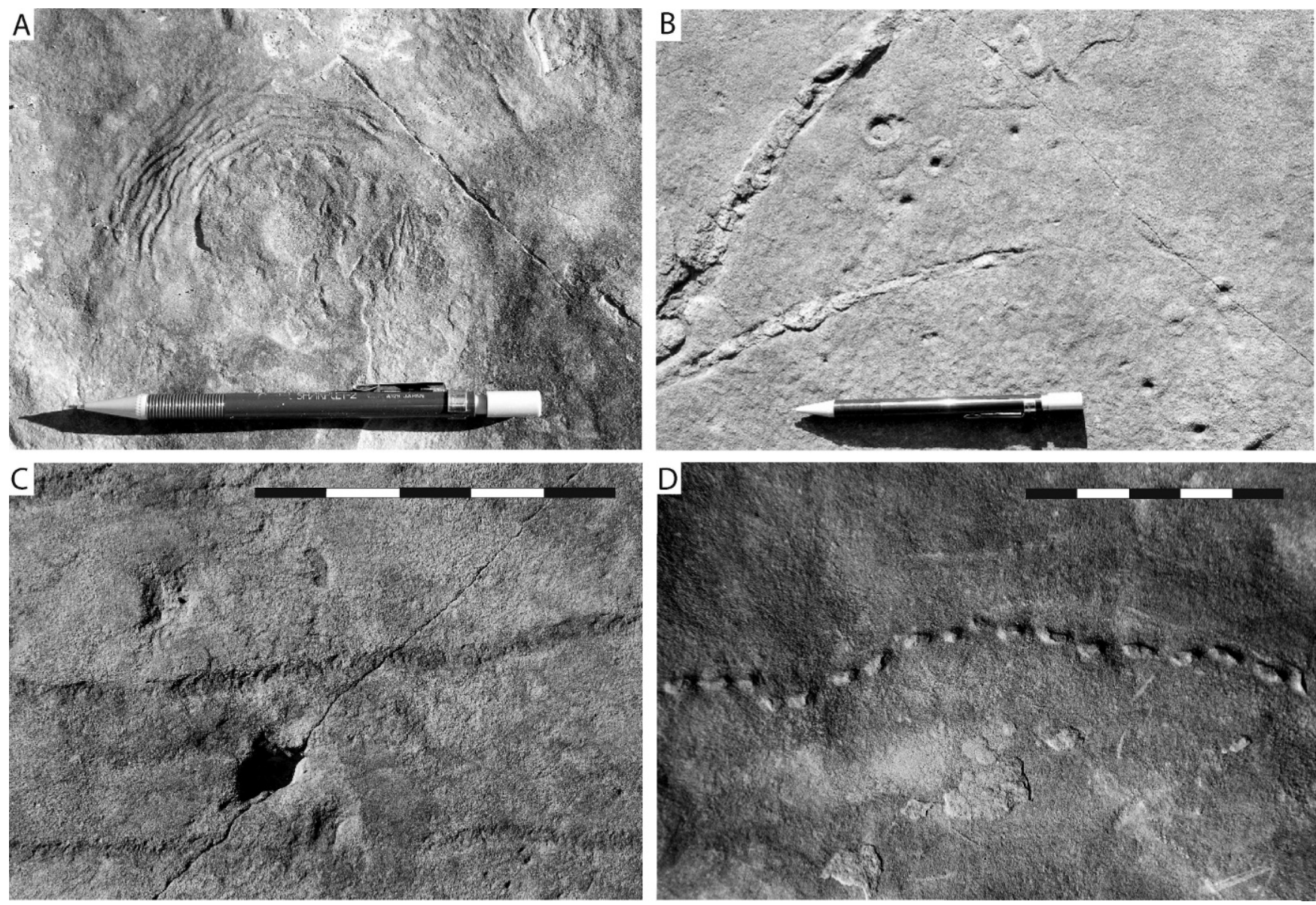

FIGURE 9-Emergence features and invertebrate trace fossils on Moyeni trackway surface. A) Wrinkle marks in very fine sandstone veneer covering rippled portion of bar surface are evidence of a short period of subaerial exposure. B) Sand volcanoes probably caused by methane escaping from decomposing organic debris while scroll bar sand was still saturated. Pencil $=15 \mathrm{~cm}$. C) Colonization of sediment after emergence by such scratch digging arthropods as beetles is evidenced by widespread occurrence of backfilled meniscate burrows (c.f. Naktodemasis) on many of the upper Elliot Formation paleosurfaces. Scale $=1 \mathrm{~cm}$ intervals. D) Beaded trails (c.f. Hormosoroidea) are interpreted as surface foraging traces (fodinichnia) of such organisms as isopods or insect larvae. Scale $=5 \mathrm{~mm}$ intervals.

(Fig. 12A). Manual digits are subequal in length and have blunt ends. Digital pads are not clear in the tracks, so it is not possible to infer manual or pedal phalangeal formulae. One of the two large Moyenisauropus-type trackways shows a relatively high pace angulation (average $160^{\circ}$ ), which suggests a narrow-gauge, upright, parasagittal gait. In contrast, the other shows a change in gauge-width, stance, and posture over the course of 17 steps. Early in the progression, the trackmaker walks with a quadrupedal, wide-gauge gait, but it changes to a narrow gauge (parasagittal) quadrupedal gait and eventually to a narrow-gauge, fully bipedal gait (J. Wilson, personal communication, 2009). In both of these Moyenisauropus-type trackways, estimated hip height of the trackmaker (Thulborn, 1989; Henderson, 2003) is $\sim 1.2 \mathrm{~m}$.
The Moyeni surface also includes numerous smaller tridactyl footprints, arranged in bipedal trackways that resemble the Moyenisauropus-type pes tracks in the absence of pointed unguals, the presence of three weight-bearing digits that are relatively broad and widely spread, digit II divergent from the two other digits, and pedes slightly rotated inward relative to the midline of travel. The footprints vary in length from 10-20 cm (Fig. 12B).

On the algal-mat-bound bar top in the northeastern portion of the trackway surface (Fig. 10), at least three resting traces attributable to the Moyenisauropus-type trackmaker are preserved (Fig. 13). In each case, the long axis of the manus and pes are parallel to one another and there is an associated, clearly defined tail impression. The pes prints are

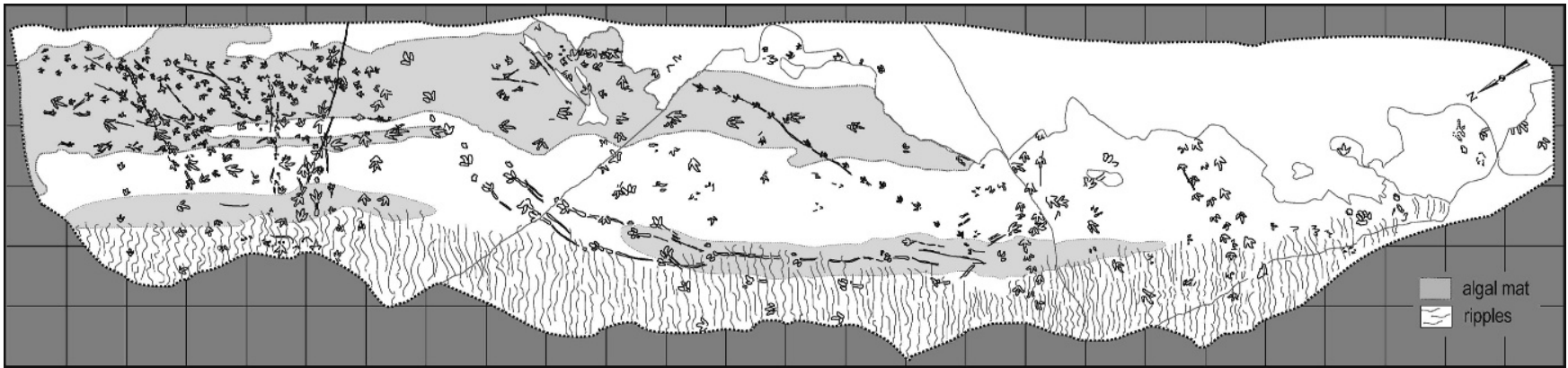

FIGURE 10-Map of tetrapod tracks on Moyeni paleosurface; note that densest cluster of small tridactyl prints is preserved on bar top in algal-mat-bound area. Grid lines = $1 \mathrm{~m}$. 


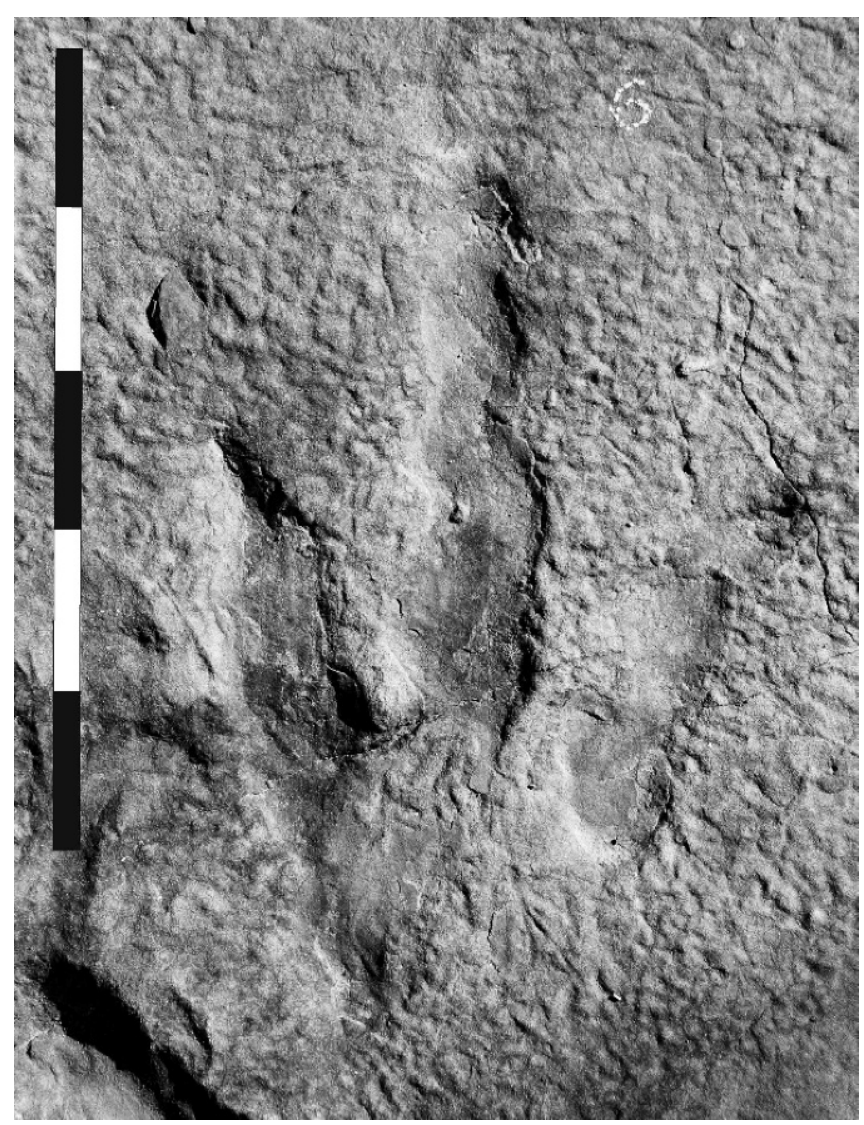

FIGURE 11-Neotrisauropus-type footprints. Field photograph of a theropod left pes impression. Note how pustular surface texture has been destroyed by footprint, suggesting that this surface was covered by a thin algal mat at time animal walked along scroll bar. Scale bar $=25 \mathrm{~cm}$.

symmetrical and preserve impressions of the three main digits (II-IV), a small digit I, and a prominent metatarsus. The pes digit impressions have pointed unguals, whereas their associated manus prints are smaller, pentadactyl, rotated outward, and do not bear ungual traces. There is no trace of pelvic structures preserved between the hind feet. Tail impressions have a U-shaped cross section, the proximal ends are rounded, and the distal ends taper and shallow gradually to a point. Two of the resting traces may have been made by the same animal, shifting its position slightly between impressions. The third was made by a different individual that faced the opposite direction. The individuals that made these resting traces are smaller than the two Moyenisauropus-type trackways described above, with an average pes length of $14 \mathrm{~cm}$.

The Moyenisauropus-type footprints are attributed to basal ornithischian trackmakers on the basis of a symmetrical, functionally tridactyl foot with blunt unguals and a pentadactyl manus having subequal digits with gently rounded tips, thus lacking enlarged or sharp unguals ( $\mathrm{J}$. Wilson, personal communication, 2009). The ichnotaxon was erected by Ellenberger (1970), who recognized several different ichnospecies that were later synonymized by Olsen and Galton (1984) with Anomoepus, a position also followed by Olsen and Rainforth (2003) in their more recent review of Anomoepus. Ellenberger (1974) acknowledged that the ichnogenus Moyenisauropus includes a good deal of variation and requires further research, which is now in progress by us.

Chirotheroid-Type Footprints.-The Moyeni surface preserves two different track types that exhibit obligate quadrupedal locomotion. One is represented by the relatively wide, sprawling Episcopopus-type trackway with a central body impression. The second is a chirotheroid-type in which the pes prints are significantly larger than the manus, pentadactyl, asymmetrical, and also bear a prominent posterolaterally everted digit $\mathrm{V}$.

There are only two sets of manus-pes impressions of this type on the southwestern end of the surface, which is an area that was not mapped by Ellenberger (1974). The two manus-pes sets are not part of the same trackway. The best-preserved set is a left manus-pes pair that is deeply impressed into the sediment, suggesting both the hind and forelimbs bore weight during the step cycle (Fig. 14). The manus is strongly rotated outward in relation to the pes and relatively smaller; it is positioned just in front of and slightly external to the pes impression. The manus is tetradactyl, with subequal digits and blunt claw marks; digit pads are not discernible. The pes is pentadactyl and asymmetrical; digits I-IV are anteriorly directed, and digit V is strongly everted. Digits III and IV are similar in length, diminishing in size toward digit I, which is the shortest of the series. Digit V is also short, everted, and has blunt claw marks. Pedal digit pads are clearer than in the manus and suggest a pedal phalangeal formula of 2-3-4-4-2 (see Parrish, 1989).

The chirotheroid-type tracks at Moyeni represent a medium-sized, quadrupedal animal with an asymmetrical pes and manus. The stout digit $\mathrm{V}$ and phalangeal formula suggests they were probably made by a basal crurotarsan archosaur (Marsicano et al., 2005), as has long been suggested for other chirotheroid-type tracks (e.g., Haubold, 1986; Parrish, 1989; Lockley and Meyer, 2000).

Episcopopus-Type Footprints.-This trackway runs diagonally across the northeastern half of the surface and exhibits a consistent manual and pedal stride length $(\sim 60 \mathrm{~cm})$, suggesting that the trackmaker maintained a constant speed (Fig. 15A). The trackway is relatively wide $(\sim 34 \mathrm{~cm})$ with shallow footprints; in places, a conspicuous smooth body impression with slightly sinuous borders is evident. The pes and manus prints are apparently pentadactyl, equivalent in size $(\sim 13 \mathrm{~cm}$ width), and only the tips of the digits are printed on the surface. Claw marks are absent in both manus and pes (Fig. 15B). The most distinctive feature of this trackway is the presence of drag marks left by both the manus and pes prints during progression. The manus drags make a pronounced S-shaped impression, whereas the pes digits form an outward curving arc that partially overprint the manus drags (Fig. 15).

The identity of the Episcopopus-type trackmaker remains unresolved. The available information derived from the trackway indicates that the animal moved with a sprawling gait and probably had short limbs that allowed its body to touch ground during the step cycle. Ellenberger (1974) originally described Episcopopus, and it is the only one of his socalled upper Stormberg ichnogenera that Olsen and Galton (1984) regarded as valid. Ellenberger (1974) attributed Episcopopus to a chelonian trackmaker, an identification that was followed by Olsen and Galton (1984). The absence of definite claw marks in the footprints, however, excludes chelonians as candidates for the trackmaker. We have collected high-resolution, three-dimensional laser scans of the Episcopopus-type trackway and are currently working to identify the trackmaker and describe its locomotion.

\section{DISCUSSION}

The upper Elliot Formation body fossil fauna has several archosaur taxa, including the small, gracile noncrocodylian crocodylomorphs (sphenosuchians) and crocodyliforms (protosuchids), and dinosaurs. Such small- to medium-sized forms as the basal theropod Syntarsus (=Coelophysis Bristowe and Raath, 2004), the ornithischians Lesothosaurus and Heterodontosaurus, and the sauropodomorph Massospondylus, which is the most common fossil tetrapod in this interval, characterize the dinosaur fauna (e.g., Kitching and Raath, 1984; Lucas and Hancox, 2001; Rubidge, 2005). The only relatively large dinosaur from the upper Elliot Formation is the recently described theropod Dracovenator (Yates, 2005), which is the potential Neotrisauropus-type trackmaker. Associated fauna include primitive chelonians (Australo- 

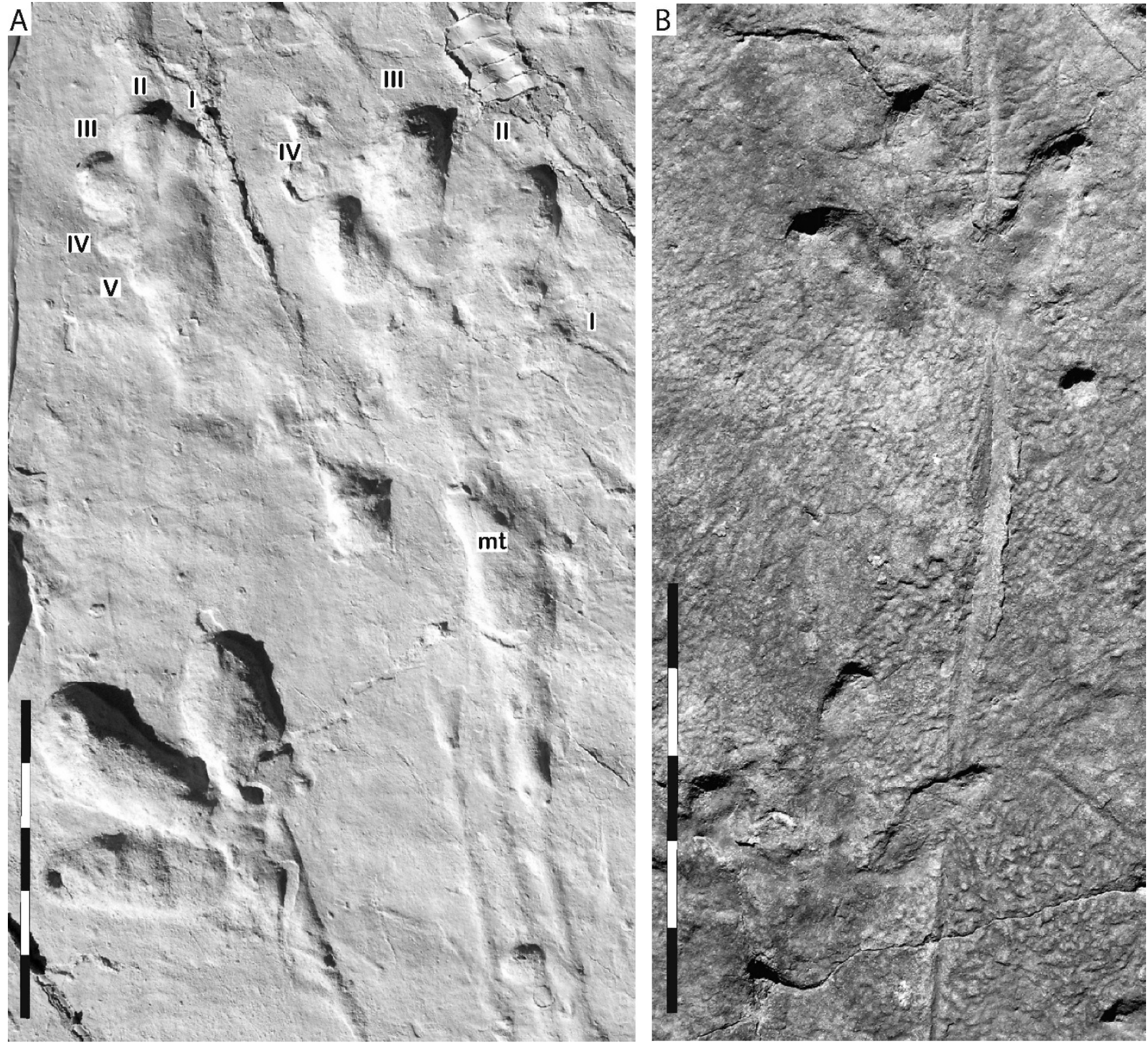

FIGURE 12-Moyenisauropus-type footprints. A) Plaster of Paris cast (positive) of a left manus-pes set illuminated from bottom left; tridactyl print lower left is part of a bipedal trackway with the same pes impression. Digits are identified with Roman numerals; $\mathrm{mt}=$ metatarsal impression. Scale bar $=10 \mathrm{~cm}$. B) Field photograph of two consecutive Moyenisauropus-type pes prints on the algal-matted portion of the bar. Note that the feet are rotated inward and have overprinted an impression interpreted as a tail drag mark. Scale bar $=25 \mathrm{~cm}$.

chelys), temnospondyls (Chigutisauridae), and numerous therapsids, including trithelodontids, tritylodontids, and basal mammals (e.g., Kitching and Raath, 1984; Lucas and Hancox, 2001; Rubidge, 2005). The Moyeni surface contains tridactyl footprints and trackways of bipeds, facultative bipeds, and quadrupeds. For the most part, the Moyeni trackways reflect the known fauna. There are some distinctive trackmakers, however, that are apparently not represented in the body fossil record. These include relatively large ornithischian dinosaurs (the large Moyenisauropus-type trackmaker) and relatively stout basal crurotarsal archosaurs (the chirotheroid-type trackmaker). In addition, the abundant fossils of the sauropodomorph Massospondylus are not mirrored in the trackway record. In fact, none of the footprints on the Moyeni surface could be confidently attributed to sauropodomorphs.

If the relative abundance of different track types is used as a rough indication of the original population dynamics, then Neotrisauropus-type and Episcopopus-type trackmakers are the least common, followed by chirotheroid-type trackmakers, with the Moyenisauropus-type basal ornithischian being by far the most abundant. The Episcopopus-type trackway is superimposed by both the Moyenisauropus-type and Neotrisauropus-type prints, the last being the most recently imprinted tracks on the surface. It is also noticeable that the definition of the digit impressions generally improves through the overprinting sequence, which implies progressive drying and firming of the fine-grained sand after emergence. It is, thus, possible that the absence of claw impressions in the many Moyenisauropus-type tracks is due to them having been made in wet, fine-grained sand that deformed thixotropically under pressure of the planted foot rather than by a clawless animal.

Regarding what the animals where doing in this area, it is clear that most of them were walking rather than running, and there is no single preferred direction to the Moyeni trackways. Analysis of the alignment of the main trackways, however, indicates three separate points where a number of trackways both converge and radiate. Two foci lie on the 

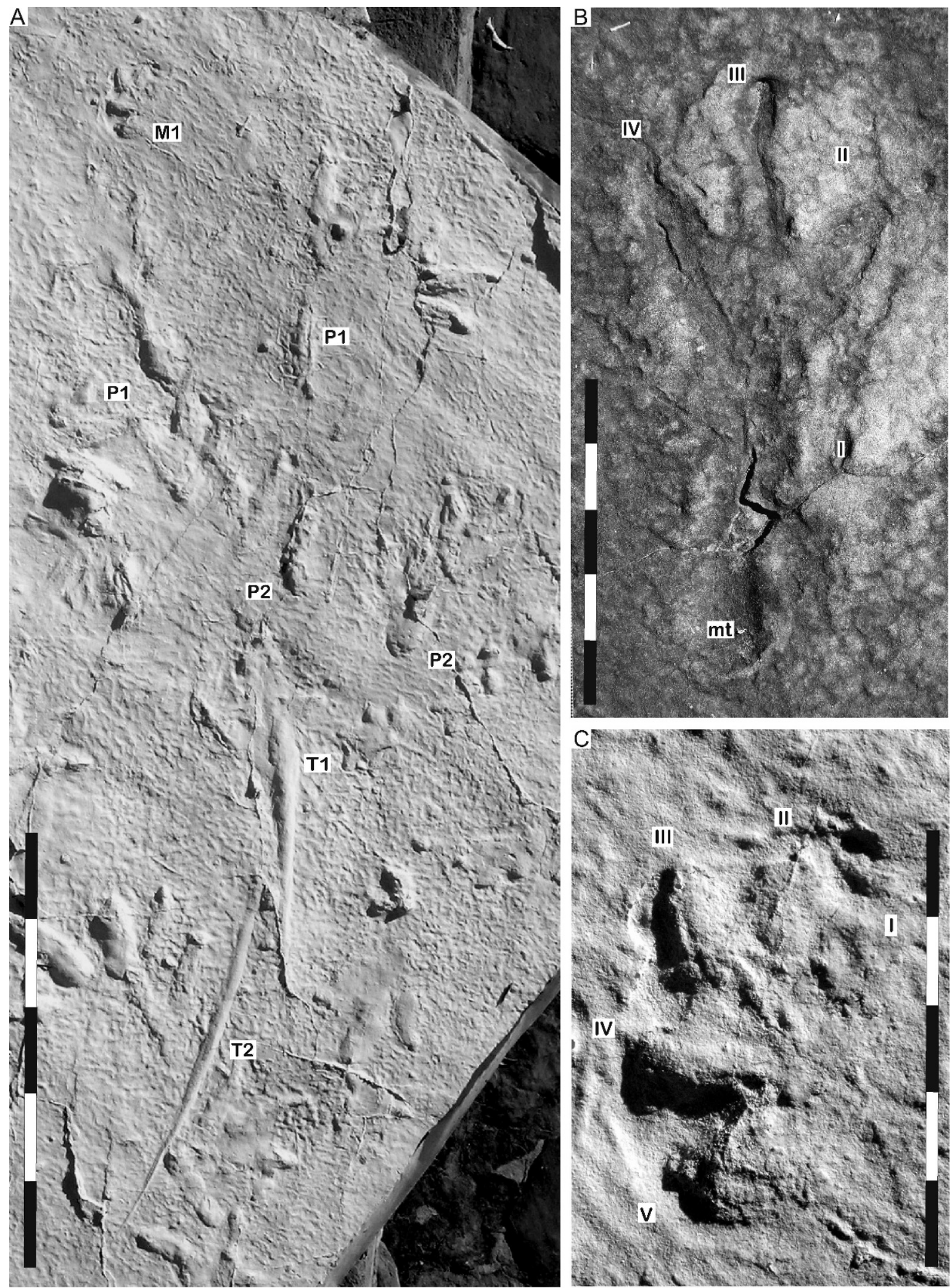

FIGURE 13-Moyenisauropus-type resting traces. A) Plaster of Paris cast (positive) of two Moyenisauropus-type resting traces, which include manus prints (M), pes prints (P), and tail drags (T); lighting from top right. Scale bar $=50 \mathrm{~cm}$. B) Field photograph of natural mold (negative) of right P2 on A; $\mathrm{mt}=$ metatarsal impression. Scale bar $=25 \mathrm{~cm}$. C) Detail of natural mold of M1. Scale bar $=10 \mathrm{~cm}$.

inferred channel side of the bar form, $\sim 18 \mathrm{~m}$ apart, and the third lies on the inner bank side of the bar. This suggests that the trackways are not strictly randomly oriented and may indicate repeated visits to access drinking or river crossing points.
The presence of chirotheroid-type footprints at Moyeni is potentially of biostratigraphic significance because of their widespread use as Triassic index fossils (e.g., Lockley and Meyer, 2000; Olsen et al., 2002; Klein and Haubold, 2007; Lucas and Tanner, 2007). Three possible 

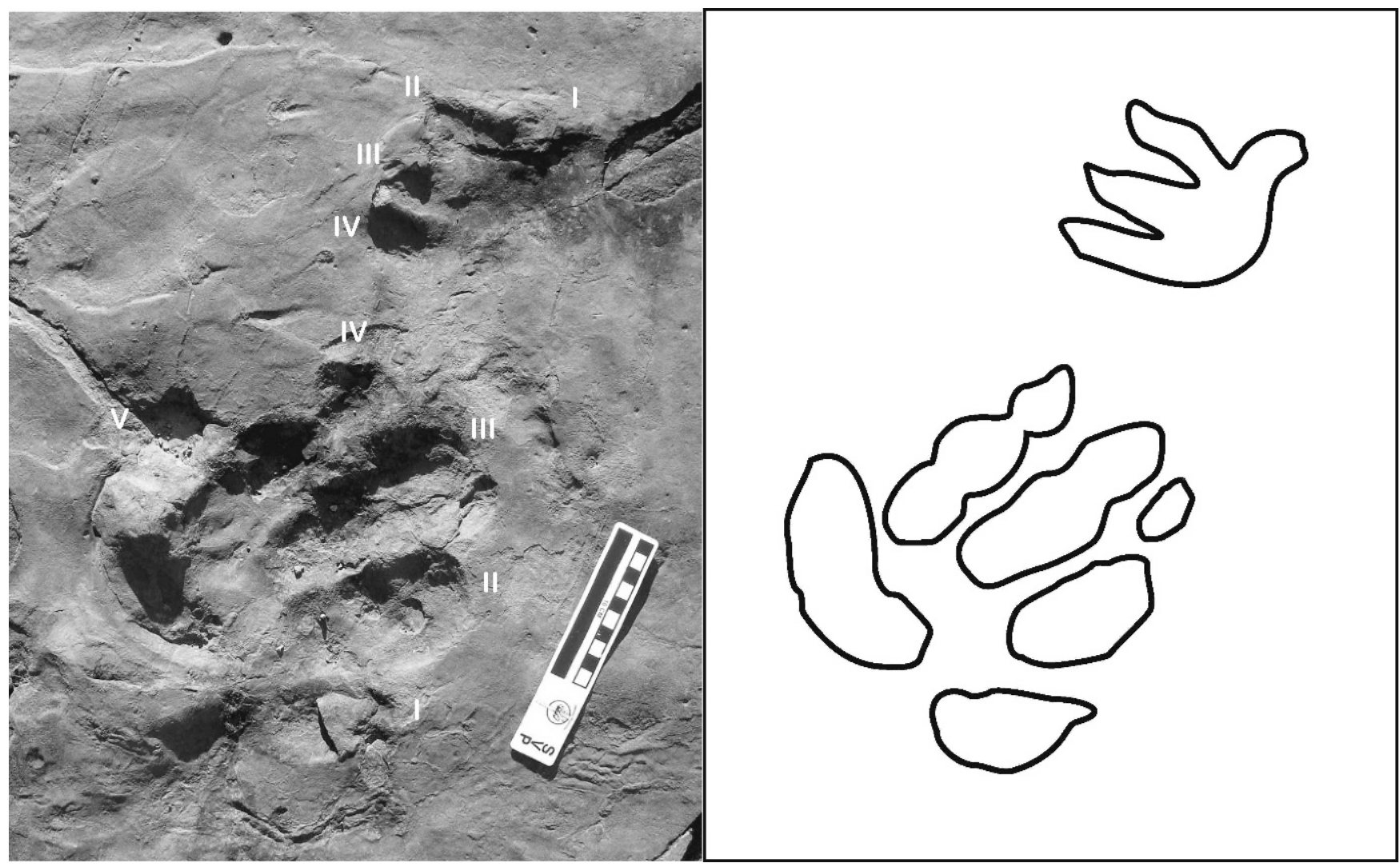

FIGURE 14-Chirotheroid-type footprints. Field photograph and interpretive outline of a left manus-pes set. Roman numerals indicate digit numbers. Scale bar $=10 \mathrm{~cm}$.

scenarios could explain their presence in this assemblage. First, the upper part of the Elliot Formation could be wrongly dated as Lower Jurassic and should be reassigned an Upper Triassic age. If this is proven correct, then this would bring all the associated fauna, including the chelonians and basal mammals, into the Late Triassic. Second, the tracks could be misidentified, and could actually belong to an ichnotaxon that is known from the Jurassic. Although we have only two manus-pes pairs, we are confident that their morphology is consistent with that of chirotheroidtype tracks described elsewhere. The third explanation is that the tracks are correctly identified and the age is correctly assigned, but the inferred range of chirotheroid-type tracks is incorrect. Deciding which scenario is correct has important implications for understanding the patterns of diversification of the Gondwanan tetrapod faunas during the early Mesozoic and the magnitude of the putative tetrapod faunal extinction at the Triassic-Jurassic boundary (e.g., Benton, 1994; Lucas and Tanner, 2007 ) in this part of Gondwana.

\section{CONCLUSIONS}

Our reappraisal of the Early Jurassic dinosaur tracksite at Moyeni in Southern Lesotho highlights the advantages of combining sedimentological, ichnological, and biomechanical approaches to the field investigation of vertebrate trackways. The main findings of this study are as follows.

1. The Moyeni trackway surface, previously thought to be a lake shore, is reinterpreted as a gently dipping pointbar surface with ridge and swale topography on the inner bank of a river meander. Moist conditions associated with early emergence are implied by a very finegrained veneer with terrestrial invertebrate traces. Many of the smaller tracks are imprinted into Kinneya-type wrinkled textures on top of the elongate bar form and were probably preserved as undertracks beneath a thin layer of filamentous algae.
2. Biomechanical analyses of the both the Moyenisauropus-type (basal ornithischian) and Neotrisauropus-type (theropod) trackways show adjustments in locomotor behavior with changes in slope and cohesiveness of the bar surface. Convergence of these trackways toward certain points indicates repeated visits perhaps for drinking or crossing the river. Three resting traces with manus, metatarsal, and tail impressions attributable to the Moyenisauropus-type have also been identified.

3. This study has highlighted a mismatch between the body fossil and trace fossil record in the Moyeni section. Footprints of the prosauropod Massospondylus, the most common body fossil, were not identified in trackways, and body fossils of the common Moyenisauropus-type basal ornithischian trackmaker have not yet been found.

4. The presence of chirotheroid-type footprints on the Moyeni surface leads us to conclude that either their global stratigraphic range should be extended into the Jurassic, or the currently accepted position of the Triassic-Jurassic boundary in the Karoo Basin should be moved higher in the succession.

\section{ACKNOWLEDGMENTS}

We thank the editor and two anonymous reviewers for their useful comments that considerably improved the readability of the manuscript. We are indebted to the South African-based Palaeontological Scientific Trust (PAST) for financing this project and Iziko South African Museum for providing logistical support. We acknowledge and thank Mrs. Khitsâne, Director of Lesotho's Department of Culture, for her ongoing support and encouragement for the project, and Sir David Ambrose of Roma University for giving us valuable information about Lesotho trackway sites. JAW's research was supported by a Woodrow Wilson Fellowship Foundation Career Enhancement Fellowship for Junior Faculty. CAM's research was supported by CONICET (Consejo Nacional de Investigaciones Científica y Técnicas, Argentina). 

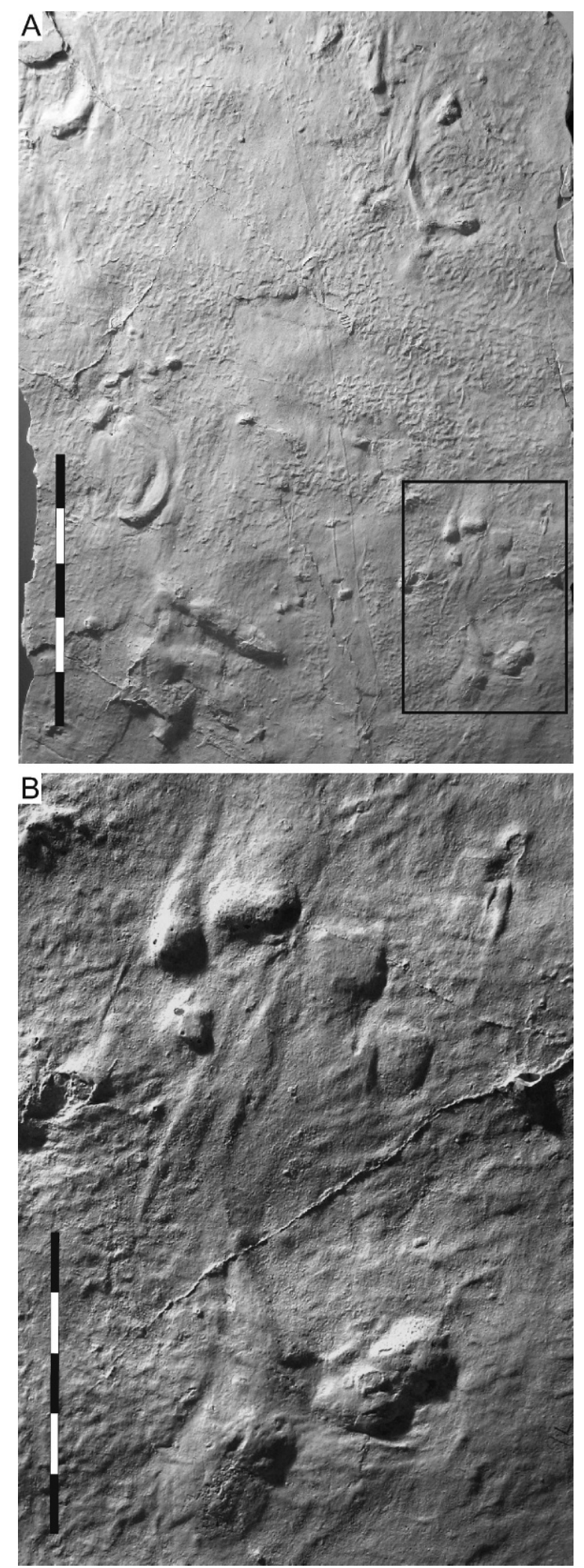

FIGURE 15-Episcopopus-type footprints. A) Plaster of Paris cast (positive) of trackway showing arcuate toe drags. Illuminated from top left, scale bar $=50 \mathrm{~cm}$. B) Detail of manus-pes impressions outlined in A. Scale bar $=20 \mathrm{~cm}$.

\section{REFERENCES}

AlLEN, J.R.L., 1963, Classification of cross-stratified units with notes on their origin: Sedimentology, v. 2, p. 93-114

Ambrose, D., 2007, Lesotho Annotated Bibliography, Palaeontology: House 9 publications, University of Lesotho, Lesotho, $130 \mathrm{p}$.

Benton, M.J., 1994, Late Triassic terrestrial vertebrate extinctions: Stratigraphic aspects and the record of the Germanic Basin: Paleontologia Lombarda Nuova Serie, v. 2, p. 19-38.

Blodgett, R.H., 1985, Palaeovertisols-Their utility in reconstructing ancient floodplain sequences: Abstracts 3rd International Fluvial Sedimentology Conference, Boulder, Colorado, p. 10.

Bordy, E.M., Hancox, P.J., and Rubidge B.S., 2004, A description of the sedimentology and palaeontology of the Late Triassic-Early Jurassic Elliot Formation in Lesotho: Palaeontologia africana, v. 40, p. 43-58.

Bristowe, A., and RaAth, M.A., 2004, A juvenile coelophysoid from the Early Jurassic of Zimbabwe, and the synonymy of Coelophysis and Syntarsus: Palaeontologia africana, v. 40, p. 31-41.

Buators, L.A., and MÁngano, M.G., 1995, The palaeoenvironmental and palaeoecological significance of the lacustrine Mermia Ichnofacies: An archetypical subaqueous nonmarine trace fossil assemblage: Ichnos, v. 4, p. 1-12.

Catuneanu, O., Hancox, P.J., and Rubidge, B.S., 1998, Reciprocal flexure behaviour and contrasting stratigraphies: A new basin development model for the Karoo retroarc foreland system, South Africa: Basin Research, v. 10, p. 417-439.

Chamberlain, C.K., 1975, Recent lebensspuren in non-marine environments, in Frey, R.W., ed., The Study of Trace Fossils: Springer Verlag, New York, p. 431-458.

Christal, F., 1897, Au sud de l'Afrique: Berger-Levrault, Nancy, France, 308 p.

Counts, J.W., and Hasiotis, S.T., 2009, Neoichnological experiments with masked chafer beetles (Coleoptera:Scarabaeidae): Implications for backfilled continental trace fossils: PALAIOS, v. 24, p. 74-91.

Duncan, R.A., Hooper, P.R., Rehacek, J., Marsh, J.S., and Duncan, A.R., 1997, The timing and duration of the Karoo igneous event, southern Gondwana: Journal of Geophysical Research, v. 102, p. 18,127-18,138.

Ellenberger, P., 1970, Les nouveaux paléontologiques de première apparition des mammifères primordiaux en Afrique du Sud et leur ichnologie: Etablissement des zones stratigraphiques détaillés dans le Stormberg du Lesotho (Afrique du Sud) (Trias Supérieur à Jurassique), in Haughton, S.H., ed., I.U.G.S., 2nd Symposium on Gondwana Stratigraphy and Palaeontology: Council for Scientific and Industrial Research, Pretoria, p. 343-370.

Ellenberger, P., 1972, Contribution à la classification des pistes de vertèbres du Trias: Les types du Stormberg d'Afrique du Sud (I): Palaeovertebrata Mémoire Extraordinaire, Laboratoire de Paléontologie des Vertèbres, Montpellier, 134 p.

Ellenberger, P., 1974, Contribution à la classification des pistes de vertèbres du Trias: Les types du Stormberg d'Afrique du Sud (II): Palaeovertebrata Mémoire Extraordinaire, Laboratoire de Paléontologie des Vertèbres, Montpellier, 104 p.

Ellenberger, P., Mossman, D.J., Mossman, A.D., and Lockley, M.G., 2006, Bushman cave paintings of ornithopod dinosaurs: Paleolithic trackers interpret Early Jurassic footprints: Ichnos, v. 12, p. 223-226.

ERIKSSON, P.G., 1985, The depositional palaeoenvironment of the Elliot Formation in the Natal Drakensberg and north-eastern Orange Free State: Transactions of the Geological Society South Africa, v. 88, p. 19-26.

Gustavson, T.C., 1991, Buried vertisols in lacustrine facies of the Pliocene Fort Hancock Formation, Hueco Bolson, West Texas and Chihuahua, Mexico: Bulletin of the Geological Society of America, v. 103, p. 448-460.

Hasiotis, S.T., 2004, Reconnaissance of Upper Jurassic Morrison Formation ichnofossils, Rocky Mountain region, USA: Environmental, stratigraphic, and climatic significance of terrestrial and freshwater ichnocoenoses: Sedimentary Geology, v. 167, p. 277-368.

Hasiotis, S.T., 2008, Reply to the comments by Bromley et al. of the paper "Reconnaissance of the Upper Jurassic Morrison Formation ichnofossils, Rocky Mountain Region, USA: Paleoenvironmental, stratigraphic, and paleoclimatic significance of terrestrial and freshwater ichnocoenoses" by Stephen T. Hasiotis: Sedimentary Geology, v. 208, p. 61-68.

Haubold, H., 1986, Archosaur footprints at the terrestrial Triassic-Jurassic transition, in Padian, K., ed., The beginning of the Age of Dinosaurs: Cambridge University Press, Cambridge, p. 189-201.

Henderson, D.M., 2003, Footprints, trackways, and hip heights of bipedal dinosaurs-Testing hip height predictions with computer models: Ichnos, v. 10, p. $99-104$.

Kent, D.V., and TauXe, L., 2005, Corrected Late Triassic latitudes for continents adjacent to the North Atlantic: Science, v. 307, p. 240-244.

Kitching, J.W., and RaAth, M.A., 1984, Fossils from the Elliot and Clarens Formations (Karoo Sequence) of the northeastern Cape, Orange Free State and Lesotho, and a suggested biozonation based on tetrapods: Palaeontologia Africana, v. 25, p. 111-125. 
Klein, H., and Haubold, H., 2007, Archosaur footprints-Potential for biochronol ogy of Triassic continental sequences, in Lucas, S.G. and Spielmann, J.A., eds., The Global Triassic: Bulletin of the New Mexico Museum of Natural History and Science, v. 41, p. 120-130.

Lockley, M.G., 1998, The vertebrate track record: Nature, v. 396, p. 429-432.

Lockley, M., and Meyer, C., 2000, Dinosaur tracks and other fossil footprints of Europe: Columbia University Press, New York, 323 p.

LuCAS, S., and Hancox, J., 2001, Tetrapod-based correlation of the nonmarine Upper Triassic of Southern Africa: Albertiana, v. 25, p. 5-9.

LuCAS, S.G., and TANNER, L.H., 2007, The nonmarine Triassic-Jurassic boundary in the Newark Supergroup of eastern North America: Earth-Science Reviews, v. 84 p. $1-20$.

Marsicano, C.A., Smith, R., and Sidor, C., 2005, Tracking the Triassic-Jurassic boundary in the roof of Africa, in Pankhust, R. and Veiga, G., eds., Gondwana 12: Geological and Biological Heritage of Gondwana, Abstracts, Academia Nacional de Ciencias, Córdoba, p. 240.

Netto, R.G., Balistieri, P.R.M.N., Lavina, E.L.C., and Silverira, D.M., 2009, Ichnological signatures of shallow freshwater lakes in the glacial Itarare Group (Mafra Formation Upper Carboniferous-Lower Permian of Parana Basin, S Brazil): Palaeogeography, Palaeoclimatology, Palaeoecology, v. 272, p. 240-255.

Olsen, P.E., and Galton, P.M., 1984, Review of the reptile and amphibian assemblages from the Stormberg of southern Africa with special emphasis on the footprints and age of Stormberg: Palaeontologia africana, v. 25, p. 87-110.

Olsen, P.E., Kent, D.V., Sues, H.-D., Koeberl, C., Huber, H., Montanari, A. Rainforth, E.C., Fowell, S.J., Szajna, M.J., and Hartline, B.W., 2002, Ascent of dinosaurs linked to an iridium anomaly at the Triassic-Jurassic boundary: Science, v. 296 , p. $1305-1307$.

Olsen, P.E., and Rainforth, E.C., 2003, The Early Jurassic ornithischian dinosaurian ichnogenus Anomoepus, in Letourneau, P.M. and Olsen, P.E., eds. The Great Rift Valley of Pangea in eastern North America II: Columbia University Press, New York, p. 314-353.

Parrish, J.M., 1989, Phylogenetic patterns in the manus and pes of early Mesozoic archosauromotph reptiles, in Gillette, D. D., and Lockley, M. G., eds., Dinosaur tracks and traces: Cambridge University Press, Cambridge, UK, p. 249-258.

Porada, O., Ghergut, J., and Bouougri, E.H., 2008, Kinneya-type wrinkle structures - Critical review and model of formation: PALAIOS, v. 23, p. 65-77.

Purkait, B., 1983, Current directions in the Usri River point-bar Bihar: Indian Journal of Earth Sciences, v. 10, p. 170-184.

ReINECK, H.-E., and SingH, I.B., 1975, Depositional sedimentary environments, with reference to terrigenous clastics: Springer Verlag, New York, 439 p.

Rowe, C.M., Loope, D.B., Oglesby, R.J., Van Der voo, R., and Broadwater, T., 2007, Inconsistencies between Pangean reconstructions and basic climate controls: Science v. 318, p. 1284-1286.
Rubidge, B., 2005, Du Toit Memorial Lecture: Re-uniting lost continents-Fossil reptiles from the ancient Karoo and their wanderlust: South African Journal of Geology, v. 108, p. 135-172.

Schumm, S.A., 1972, Fluvial paleochannels, in Rigby, J.K. and Hamblin, W.K., eds., Recognition of Ancient Sedimentary Environments: Society of Economic Palaeontologists and Mineralogists Special Publication, v. 16, p. 98-107.

SHEPHERD, R.G., 1987, Lateral accretion surfaces in ephemeral-stream point bars, Rio Puerco, New Mexico, in Ethridge, F.G., Flores, R.M., and Harvey, M.D. eds. Recent Developments in Fluvial Sedimentology: Society of Economic Palaeontologists and Mineralogists Special Publication, v. 39, p. 93-98.

Smith, J.J., and Hasiotis, S. T., 2008, Traces and burrowing behaviors of the cicada nymph Cicadetta calliope: Neoichnology and paleoecological significance of extant soil-dwelling insects: PALAIOS, v. 23, p. 503-513.

Smith, J.J., Hasiotis, S.T., Kraus, M.J., and Woody, D.T, 2008, Naktodemasi bowni: New ichnogenus and ichnospecies for adhesive meniscate burrows (AMB), and palaeoenvironmental implications, Palaeogene Willwood Formation, Bighorn Basin, Wyoming: Journal of Paleontology, v. 82, p. 267-278.

SмiтH, R.M.H., 1993, Sedimentology and ichnology of floodplain palaeosurfaces in the Beaufort Group (Late Permian), Karoo Sequence, South Africa: PALAIOS, v 8, p. 339-357.

Smith, R.M.H., Eriksson, P.G., and Botha, W.J., 1993. A review of the stratigraphy and sedimentary environments of the Karoo-aged Basins of southern Africa: Journal of African Earth Sciences, v. 16, p. 143-169.

SмiтH, R.M.H., and Kiтching, J., 1997, Sedimentology and vertebrate taphonomy of the Tritylodon Acme Zone: A reworked paleosol in the Early Jurassic Elliot Formation, Karoo Supergroup, South Africa: Palaeogeography, Palaeoclimatology, Palaeoecology, v. 131, p. 29-50.

Thulborn, R.A., 1989, The gaits of dinosaurs, in Gillette, D.D. and Lockley, M.G., eds., Dinosaur Tracks and Traces: Cambridge University Press, Cambridge, UK, p. $39-50$.

Thulborn, R.A., 1990, Dinosaur Tracks: Chapman and Hall, London, 410 p.

Visser, J.N.J., and BothA, B.J.V., 1980, Meander channel, point bar, crevasse splay and aeolian deposits from the Elliot Formation in Barkly Pass, north-eastern Cape: Transactions of the Geological Society South Africa, v. 83, p. 55-62.

WARD, J.D., 1987, The Cenozoic succession in the Kuiseb valley, Central Namib Desert: Geological Survey of South West Africa/Namibia, Memoir 9, 124 p.

Yates, A.M., 2005, A new theropod from the Early Jurassic of South Africa and its implications for the early evolution of theropods: Palaeontologia africana, v. 41, p. $105-122$

ACCEPTED JUNE 27, 2009 